\title{
INTERNATIONAL COMPETITIVE POSITIONS OF THE BALTIC STATES - CHANGES AND DETERMINANTS IN THE POST-ACCESSION PERIOD
}

\author{
Edward MOLENDOWSKI (D) ${ }^{*}$, Vladislavas PETRAŠKEVIČIUS ${ }^{2}$ \\ ${ }^{1}$ Department of International Economic Relations, Faculty of Economics and \\ International Relations, Cracow University of Economics, Cracow, Poland \\ ${ }^{2}$ Department of Economics Engineering, Faculty of Business Management, \\ Vilnius Gediminas Technical University, Vilnius, Lithuania
}

Received 19 May 2019; accepted 06 January 2020

\begin{abstract}
The article presents the results of an analysis comparing changes in the competitive positions of the Baltic States in comparison with the Visegrad Group countries and the new EU Member States in the post-accession period (2006-2017). This type of study has not been presented in more detail in the available literature. Researchers of international economic competitiveness mostly focussed on the EU-15. The Baltic States mainly have been excluded from such investigations. Therefore, the article may significantly contribute to bridging the gap.

The study employs the method of secondary data's comparative analysis concerning indices and pillars of economic competitiveness described in The Global Competitiveness Reports of the World Economic Forum. An important element of the examination was to identify major determinants of those developments. It focussed on the identification of structural factors shaping the competitive positions of the countries covered. The demonstration which of the factors determine competitiveness and the assessment of long-term changes may serve as the basis for economic policy making. The assumption is that the EU accession had a considerable impact on the development of the competitive position but specific effects varied between countries. The Baltic States differed rather widely regarding the improvement of their competitive positions throughout the post-accession period.
\end{abstract}

Keywords: international economic competitiveness, international competitiveness of an economy, effects of EU membership, Baltic States, Visegrad Group countries, new EU Member States.

JEL Classification: E2, E6, F4, F5.

\section{Introduction}

In the post-accession period, the new EU Member States have experienced a number of successes and failures. The accession to the EU resulted in more changes in addition to those initiated in the early 1990s, whilst the first years of membership allowed to build

*Corresponding author. E-mail: edward.molendowski@uek.krakow.pl

This is an Open Access article distributed under the terms of the Creative Commons Attribution License (http://creativecommons. org/licenses/by/4.0/), which permits unrestricted use, distribution, and reproduction in any medium, provided the original author and source are credited. 
relatively firm and stable foundations for further development. Those became the main determinant of strengthening the international competitive positions of their economies. As a result of the accession to the European Union, the majority of the new Member States experienced rapid economic growth that was accompanied by restructuring and modernisation. It considerably improved the international competitive positions of their economies. This problem is analysed by many researchers and widely presented in the literature (for more see: Molendowski, 2015).

The article aims to present the results of an analysis seeking to compare changes in the competitive positions of the Baltic States (Lithuania, Latvia and Estonia) in comparison with the Visegrad Group (V4) countries and the new EU Member States (EU-10) ${ }^{1}$ in the postaccession period (2006-2017). In addition, an important element of the examination is the comparison with Poland, which is considered in the literature as a country that had experienced the most successesV4 country in terms of economic competitiveness improvement in the post-accession period (Molendowski \& Folfas, 2019; Wołkonowski, 2019).

In the presented study, the competitiveness of an economy is understood as the country's ability to strengthen its position in international markets, to increase its investment attractiveness and, as a result, to obtain sustainable improvement of the quality of life. Following other authors it was assumed that the competitiveness of an economy should be described from the angle of the development of available (domestic and foreign) production factors, the ability to take opportunities related to ongoing globalisation and the adaptability of businesses, sectors and the economy as a whole to changing conditions in the external environment, thus - the achievement of development objectives (for more see: Żmuda \& Molendowski, 2016). Such an approach to economic competitiveness was adopted by the authors of the Global Competitiveness Reports written by researchers of the World Economic Forum.

The analysis was based on the indicators presented in the Global Competitiveness Reports prepared by the World Economic Forum. The reports contain some of the most comprehensive and most frequently quoted rankings of international economic competitiveness. The research method used is the so-called "desk research", i.e. identification of available data, their processing and multidimensional comparative analysis.

The analysis assumes that the EU accession had a considerable impact on the development of the competitive position but specific effects varied between countries. The examination also attempts to identify the influence of the most important factors (pillars) concerning the competitive positions of the countries covered in the analysed period. According to the World Economic Forum experts, the Baltic States should already be at a stage of building their competitive positions based on efficiency enhancers as well as on innovation and sophistication factors. The analysis presented in the article aims to verify that assumption.

This objective determined the structure of the article. The text begins with a brief introduction indicating the context and purpose of the study. The substantive part of the article is divided into four sections. The first section presents a review of major publications in the literature concerning the phenomenon of competitiveness and the international competitive position of an economy. Section two describes the measures and methods of the measure-

\footnotetext{
${ }^{1}$ The group comprises the countries having joined the EU in 2004 and 2007. The study excludes Malta and Cyprus due to significantly different characteristics of their economies.
} 
ment of international economic competitiveness applied in the study presented. Sections three and four discuss the most important findings from the analysis. The focus is on the description of changes in the competitive positions of the Baltic States and on the factors determining those developments in the post-accession period (2004-2017). The performance of the countries covered are presented against the backdrop of the respective results obtained by Poland, the other Visegrad Group countries and the new EU Member States.

It is worth emphasising that the international competitiveness of economies has been addressed by a number of researchers but the literature continues to lack studies and analyses covering the Baltic States or the new EU Member States. Only a few studies can be included on this topic: Espona (2018), Falkowski (2018), Kerikmäe, Chochia, and Atallah (2018), Misztal (2009), Wołkonowski (2018).

The added value of the article is the presentation of the most important results achieved in the process of building the international competitive position of economies by the Baltic States against the background of results recorded by Poland, other Visegrad Group countries and the New Member States of the EU. It seems that the present article may be an important complement to the research gap that still exists in this area.

\section{Competitiveness and the international competitive position of an economy - a review of major publications in the literature}

Recently, the issue of economic competitiveness has attracted significantly increased interest from both scholars and practitioners. The notion fuels much controversy, being rather frequently interpreted a number of ways (Wziątek-Kubiak, 2004). The economist to present the fiercest 'attack' on the concept of the competitiveness of an economy was P. Krugman. He considered drawing an analogy between the competitiveness of corporations and that of countries to be meaningless and contrary to foreign trade theories (Krugman, 1994).

In his criticism, P. Krugman put forward three arguments:

1) There is no simple translation of the operation of an enterprise into the functioning of an economy as a whole. Corporations which become uncompetitive fall into financial distress over time and, as a result, cease to exist. There is no such situation in the case of countries; even if they perform very poorly in economic terms, they do not vanish from the market so it is pointless to consider their competitiveness;

2) Countries do not compete between each other in the same way as businesses do. If an undertaking offers more competitive products and services, it 'wins financially' at the expense of a less competitive one. Therefore, it is a zero-sum game. Applying this to the macroeconomic level would mean that one country's success would translate into another country's loss, thus the existence of winners and losers in foreign trade. International trade - obviously - may benefit all players at the same time. Thus, there are no grounds to adopt such an assumption;

3) Export competitiveness determines the success of small and open economies. However, in the case of larger and more self-sufficient ones economic growth hinges on their ability to efficiently use and redistribute any resources generated rather than 
on international trade performance. Therefore, the phenomenon of competitiveness is not a universal idea.

The criticism of considering competitiveness at the country level elicited a sharp reaction from the academic community. In the same journal in which Krugman had published his article three prominent economists: Prestowitz (1994), Thurow (1994), Cohen (1994) polemised with him. In the following years, a number of papers were published on the subject concerned.

In reply to Krugman's arguments, it is mostly emphasised that:

1) It is worth looking at the issue as a long-term phenomenon, with structural characteristics (Wziątek-Kubiak, 2001). Certain authors point out that it is an element distinguishing economic competitiveness from business or sectoral competitiveness. In the long term, the competitiveness of an economy may be improved through the development of trade specialisation as a result of structural adjustments and qualitative changes. Therefore, economic competitiveness is inextricably connected with economic development and must be seen as a dynamic category (Jagiełło, 2008; Weresa, 2008).

2) At present, national economies are international competitors. Obviously, the comparative advantage theory, referred to by Krugman in his criticism, is based on a central assumption of the lack of factor mobility. However, in conditions of the free movement of production factors competition is reflected in rivalry for those factors. A more efficient use of production factors, in particular of intangible resources (innovation, cultural standards, organisation and management skills), becomes the foundation for structural adjustments and leads to changes in the competitiveness of economic sectors (Radło, 2008).

3) Due to ongoing globalisation and the convergence of consumer preferences on a global scale, producers from large countries - and mainly relying on domestic sales - are exposed to competition from innovative foreign products. In the days of a global economy, international rivalry at the corporation level spreads to national markets. As a result, even a large and industrialised economy cannot ignore competitive pressure from innovation leaders or more competitive foreign businesses. In open-economy conditions, capabilities to take globalisation-related opportunities but also to cope with threats from international competitors are reflected in job creation in the country concerned and, as a consequence, in economic growth (Howes, 2000).

The arguments presented above allow to justify addressing the competitiveness of national economies in the days of ongoing globalisation. Supporters of the concept of economic competitiveness believe it to be a 'modern' approach to fundamental problems of economic development in conditions of globalisation. In their opinion, the central issue to be considered with regard to the international competitiveness of an economy is an attempt to answer the questions why countries vary in socio-economic performance, what are the reasons for such differences as well as how to shape national development and to improve the welfare of the population based on the maximisation of long-term benefits of international trade (Reinert, 1995; Wysokińska, 2001; Martin, 2003). 
However, it remains open to question how to define the substance of the phenomenon. A snowballing increase in the number of opinions voiced on economic competitiveness has led to chaotic concepts (Gomułka \& Czajkowski, 2008). However, despite terminological incoherence, it is commonly accepted that the notion of the international competitiveness of an economy can be divided into supplementary outcome- and factor-based elements (Radło, 2008).

Outcome-based competitiveness - referred to as the competitive position - represents the place of a country in the global economy (Weresa, 2008). It is reflected in the country's share in broadly defined international trade, indicating the position achieved in trade in goods, services and in international flows of production factors (Misala, 2011). The competitive position is related to both the volume and structure of such trade. An increased proportion of exports of high-technology goods, based on knowledge and innovation, are reflected in the country's relatively better competitive position. The situation translates into the country's position and advancement in the modern international division of labour and, consequently, through increased salaries and wages, into improved welfare of the population (Wysokińska, 2001).

Factor competitiveness is defined by J. Bossak (2000) as the ability to struggle, to compete for benefits related to the participation of a country in the international division of labour. It is built on the basis of available domestic resources and the ability to make use of external conditions related to developments in the world economy. However, a competitive advantage is only created by the effectiveness of using competitiveness in dynamic terms, including the ability to employ increasingly advanced factors (Weresa, 2008, 2018).

It must be emphasised that each of the categories described above is relative in nature; it must be considered in relation to other countries but also in the context of the development stage of the economy under investigation. (For more on the subject see: Żmuda \& Molendowski, 2016).

The competitive position of the Baltic countries' economies has so far been rarely analysed in the literature. Only a few publications belong to the most important ones. The publication of Misztal (2009) was one of the first analysing the international competitiveness of the Baltic States. However, it relates to period 1996-2006. According to the author, in this period, the Baltic countries experienced a gradual growth of competitiveness and competitive position. He explains the improvements needed to increase their international competitiveness, such as continuation of structural reforms, introducing gradually a knowledge based economy, public finance reforms. According to Espona (2018), the Baltic countries can bring significantly contribute to regional geostrategic cohesion, allowing the improvement of their competitive position. Wołkonowski (2018), assessing the effects of the adoption of the euro by the Baltic countries to date, states that it contributed moderately positively to the economic performance of Slovakia, Latvia and Lithuania, and definitely positively to the improvement of economic growth in Estonia. Kerikmäe, Chochia, and Atallah (2018) stated that the Baltic countries had no doubts as to their integration with the EU from the very beginning of the transformation. To this end, they cooperated closely. This allowed them to improve their position in the international arena. Falkowski (2018), assessed the international competitiveness of the Baltic States regarding trade in 
high-technology goods between 1997 and 2014. He concluded that their international competitiveness in this aspect was relatively low.

With reference to the adopted objective of the analysis presented in the article, it seems justified to examine changes in the competitive position and its determinants with regard to the Baltic States in the period from their joining the European Union.

\section{Measures and methods of the measurement of international economic competitiveness}

The international competitiveness of an economy is assessed by determining the competitive position (Bossak, 2000) or the competitive ability (Misala, 2009) of the economy in question. In recent years, there have been various measures of the international competitiveness of national economies, thus a number of measurement methods. It concerns both measuring the competitiveness of the economy of a country and its international competitive position in the period under analysis. The determinants of the competitiveness of individual countries have been investigated by many researchers and international centres.

One of them is the International Institute for Management Development [IMD]. It publishes its research results in annual reports entitled the World Competitiveness Yearbook, covering several dozen countries (IMD, 2017). In addition, since 2004, the World Bank has prepared annual Doing Business reports investigating the conditions of pursuing economic activities in the countries under examination (The World Bank, 2018). Assessments of international economic competitiveness relatively often rely on the Foreign Direct Investment Confidence Index prepared on an annual basis by the consulting firm A.T. Kearney. The international competitiveness of a country is also measured by the Human Development Index (HDI), a composite measure of the quality of life in the country concerned, published annually by the (United Nations Development Programme [UNDP], 2018).

In recent years, one of the most comprehensive and most frequently quoted rankings has been that of the international competitiveness of economies (The Global Competitiveness Report). This ranking is a comparative study of conditions of economic development in individual countries prepared annually by the World Economic Forum [WEF] $]^{2}$. The countries analysed are ranked in terms of competitiveness, which is measured by an index developed for this purpose. In accordance with the ranking done in 2017, it was calculated on the basis of 114 factors grouped into 12 pillars divided into 3 categories with regard to specific countries. These included: basic requirements, efficiency enhancers as well as innovation and

\footnotetext{
2 The report was first published in 1979 and has gradually covered an increasing number of countries (140 in 2017). Initially, it contained a ranking based on the Competitiveness Index designed under the supervision of Prof J. Sachs, indicating the foundations of fast economic development in the medium and long term. In 2000, at the initiative of Prof J. Sachs, a new index calculation methodology was introduced and the name was changed to the Growth Competitiveness Index, to distinguish it from the current microeconomic competitiveness index used under various names in a number of reports. In 2004, it was replaced by the Global Competitiveness Index, covering not only macroeconomic determinants but also microeconomic factors facilitating an assessment of the ability of a country to achieve economic growth. Another modification of the index was introduced in 2008 at the initiative of Prof M.E. Porter and consisted in the inclusion of productivity determinants, believed to significantly influence the standards of living in individual countries. (WEF, 2008). Data currently published by the WEF according to the methodology concerned cover a period from 2006.
} 
sophistication factors. With regard to each determinant, individual countries receive scores between 1 and 7 where 1 denotes the lowest and 7 - the highest possible score. The list of factors used to establish the competitive position of the countries covered is presented in Table 1.

Table 1. The Global Competitiveness Index framework (according to the Global Competitiveness Report) (source: WEF, 2017)

\begin{tabular}{|l|l|l|}
\hline \multicolumn{1}{|c|}{$\begin{array}{c}\text { Basic requirements } \\
\text { sub-index }\end{array}$} & \multicolumn{1}{|c|}{$\begin{array}{c}\text { Efficiency enhancers } \\
\text { sub-index }\end{array}$} & $\begin{array}{l}\text { Innovation and sophistication } \\
\text { factors sub-index }\end{array}$ \\
\hline $\begin{array}{l}\text { Pillar 1. Institutions } \\
\text { Pillar 2. Infrastructure } \\
\begin{array}{l}\text { Pillar 3. Macroeconomic } \\
\text { environment } \\
\text { Pillar 4. Health and } \\
\text { primary education }\end{array}\end{array}$ & $\begin{array}{l}\text { Pillar 5. Higher education and training } \\
\text { Pillar 6. Goods market efficiency } \\
\text { Pillar 7. Labour market efficiency } \\
\text { Pillar 8. Financial market development } \\
\text { Pillar 9. Technological readiness } \\
\text { Pillar 10. Market size } \\
\text { Basic requirements }\end{array}$ & $\begin{array}{l}\text { Pillar 11. Business } \\
\text { sophistication } \\
\text { Pillar 12. Innovation }\end{array}$ \\
\hline \multicolumn{1}{|c|}{$\downarrow$} & \multicolumn{1}{|c|}{$\downarrow$} & $\downarrow$ \\
\hline $\begin{array}{l}\text { Key for factor-driven } \\
\text { economies }\end{array}$ & Key for efficiency-driven economies & $\begin{array}{l}\text { Key for innovation-driven } \\
\text { economies }\end{array}$ \\
\hline
\end{tabular}

In order to compute the composite indicator of the competitive position, it is essential to place the country concerned in the relevant group defining its stage of development. The weights assigned to specific pillar groups depend on the value of GDP per capita of the country in question. Those are presented in Table 2.

Table 2. Weights of the determinants of the competitive position of a country according to the stage of development (GDP per capita) (source: WEF, 2017)

\begin{tabular}{|l|c|c|c|c|c|}
\hline \multicolumn{1}{|c|}{ Specification } & $\begin{array}{c}\text { Stage 1: } \\
\text { factor-driven }\end{array}$ & $\begin{array}{c}\text { Transition } \\
\text { from stage 1 } \\
\text { to stage 2 }\end{array}$ & $\begin{array}{c}\text { Stage 2: } \\
\text { efficiency- } \\
\text { driven }\end{array}$ & $\begin{array}{c}\text { Transition } \\
\text { from stage 2 } \\
\text { to stage 3 }\end{array}$ & $\begin{array}{c}\text { Stage 3: } \\
\text { innovation- } \\
\text { driven }\end{array}$ \\
\hline GDP per capita (in USD) & $<2000$ & $2,000-2,999$ & $3,000-8,999$ & $9,000-17,000$ & $>17,000$ \\
\hline $\begin{array}{l}\text { Weight for basic } \\
\text { requirements (in \%) }\end{array}$ & 60 & $40-60$ & 40 & $20-40$ & 20 \\
\hline $\begin{array}{l}\text { Weight for efficiency } \\
\text { enhancers (in \%) }\end{array}$ & 35 & $35-50$ & 50 & 50 & 50 \\
\hline $\begin{array}{l}\text { Weight for innovation } \\
\text { and sophistication factors } \\
\text { (in \%) }\end{array}$ & 5 & $5-10$ & 10 & $10-30$ & 30 \\
\hline
\end{tabular}

As shown by the data presented in Table 2, in the WEF ranking the basic requirements are of key importance to economies whose development is mostly based on traditional factors of production (their GDP per capita does not exceed USD 2,000). Efficiency enhancers are crucial for economies mainly driven by investment (GDP per capita of USD 3,000 to USD $17,000)$. Innovation and sophistication factors are particularly vital to countries whose development is innovation-driven. Those are countries at the top (third) stage of economic devel- 
opment (their GDP per capita exceeds USD 17,000). It is worth emphasising that efficiency enhancers were assigned relatively the highest weight among the determinants of a country's competitive position. At the same time, basic requirements play a relatively significant role in defining the competitive position of the lowest-income countries. The classification of the countries covered by the presented analysis based on those assumptions is shown in Table 3 ).

Table 3. Classification of the EU-10 by stage of development with GDP per capita thresholds (source: WEF, 2006, 2017)

\begin{tabular}{|l|l|l|}
\hline \multirow{2}{*}{ Stage of development } & \multicolumn{2}{|c|}{ Years } \\
\cline { 2 - 3 } & \multicolumn{1}{|c|}{2006} & \multicolumn{1}{c|}{2017} \\
\hline Stage 2: efficiency-driven & $\begin{array}{l}\text { Bulgaria, Lithuania, Latvia, } \\
\text { Poland, Romania, Slovakia }\end{array}$ & Bulgaria \\
\hline $\begin{array}{l}\text { Transition from stage 2 to } \\
\text { stage 3 }\end{array}$ & $\begin{array}{l}\text { Czech Republic, Estonia, } \\
\text { Hungary }\end{array}$ & $\begin{array}{l}\text { Lithuania, Latvia, Poland, } \\
\text { Romania, Hungary, Slovakia }\end{array}$ \\
\hline Stage 3: innovation-driven & Slovenia & $\begin{array}{l}\text { Czech Republic, Estonia, } \\
\text { Slovenia }\end{array}$ \\
\hline
\end{tabular}

It follows from the above presentation that the weights in the 2006-2017 WEF Reports considerably changed for particular determinants of the international competitive positions of the EU-10 economies. According to this assumption, in 2006, in the case of the majority (six) of the countries covered the competitive position should be shaped mostly (in 50\%) by efficiency enhancers and basic requirements (in 40\%). In contrast, in 2017, six of the countries under analysis should show significantly diminished importance of basic requirements (from $40 \%$ to $30 \%$ ) in favour of innovation and sophistication factors (from 10\% to $10-30 \%$ ), whereas in three of them the most essential role, in addition to efficiency enhancers (50\%), should be played by innovation and sophistication factors (30\%).

\section{Changes of the competitive positions of the Baltic States}

According to the results of the studies on the economic competitiveness carried out by WEF, during the first years following the EU accession the Baltic States ranked relatively low in terms of competitiveness and international position (compared to the countries covered) (cf. Table 4).

Table 4. Positions of the Baltic States against the backdrop of Poland, the V4 countries and the EU-10 in 2006-2017* in the competitiveness studies conducted by the WEF (source: Own calculations based on WEF, 2015, 2017)

\begin{tabular}{|c|c|c|c|c|c|c|c|c|c|c|c|c|}
\hline \multirow{2}{*}{ Year } & \multicolumn{6}{|c|}{ Rank } & \multicolumn{7}{c|}{ Score } \\
\cline { 2 - 16 } & EE & LT & LV & PL & V4 & EU-10 & EE & LT & LV & PL & V4 $^{\mathrm{a}}$ & EU-10 \\
\hline 2006 & 26 & 39 & 44 & 45 & 38 & 45 & 4.82 & 4.49 & 4.47 & 4.39 & 4.52 & 4.43 \\
\hline 2007 & 27 & 38 & 45 & 51 & 43 & 47 & 4.74 & 4.49 & 4.41 & 4.28 & 4.41 & 4.37 \\
\hline 2008 & 32 & 44 & 54 & 53 & 49 & 51 & 4.67 & 4.45 & 4.26 & 4.28 & 4.38 & 4.35 \\
\hline 2009 & 35 & 53 & 68 & 46 & 46 & 52 & 4.56 & 4.30 & 4.06 & 4.33 & 4.38 & 4.31 \\
\hline
\end{tabular}


End of Table 4

\begin{tabular}{|c|c|c|c|c|c|c|c|c|c|c|c|c|}
\hline \multirow{2}{*}{ Year } & \multicolumn{9}{|c|}{ Rank } & \multicolumn{7}{c|}{ Score } \\
\cline { 2 - 14 } & EE & LT & LV & PL & V4 & EU-10 & EE & LT & LV & PL & V4 $^{\mathrm{a}}$ & EU-10 \\
\hline 2010 & 33 & 47 & 70 & 39 & 47 & 52 & 4.61 & 4.38 & 4.14 & 4.51 & 4.41 & 4.35 \\
\hline 2011 & 33 & 44 & 64 & 41 & 49 & 55 & 4.62 & 4.41 & 4.24 & 4.46 & 4.38 & 4.33 \\
\hline 2012 & 34 & 45 & 55 & 41 & 53 & 54 & 4.64 & 4.41 & 4.35 & 4.46 & 4.36 & 4.35 \\
\hline 2013 & 32 & 48 & 52 & 42 & 57 & 56 & 4.65 & 4.41 & 4.40 & 4.46 & 4.31 & 4.34 \\
\hline 2014 & 29 & 41 & 42 & 43 & 54 & 51 & 4.71 & 4.51 & 4.50 & 4.48 & 4.36 & 4.40 \\
\hline 2015 & 30 & 36 & 44 & 41 & 51 & 48 & 4.74 & 4.55 & 4.45 & 4.49 & 4.41 & 4.43 \\
\hline 2016 & 30 & 35 & 49 & 36 & 50 & 48 & 4.78 & 4.60 & 4.45 & 4.56 & 4.44 & 4.47 \\
\hline 2017 & 29 & 41 & 54 & 39 & 47 & 48 & 4.85 & 4.58 & 4.40 & 4.59 & 4.51 & 4.51 \\
\hline Change & & & & & & & & & & & & \\
\hline $\begin{array}{c}2009 / \\
2006\end{array}$ & -9 & -14 & -24 & -1 & -8 & -7 & 0.03 & 0.10 & -0.07 & 0.21 & -0.01 & 0.08 \\
\hline $\begin{array}{c}2017 / \\
2009\end{array}$ & 6 & 12 & 14 & 7 & -2 & 4 & -0.26 & -0.19 & -0.41 & -0.06 & -0.14 & -0.12 \\
\hline $\begin{array}{c}2017 / \\
2006\end{array}$ & -3 & -2 & -10 & 6 & -10 & -3 & 0.29 & 0.29 & 0.34 & 0.27 & 0.13 & 0.20 \\
\hline
\end{tabular}

Notes: ${ }^{\star}$ The data presented in this table only cover a period from 2006 as the WEF rankings for previous years were based on a different classification of pillars of the competitive positions of the countries analysed. a The arithmetic mean for the whole group of countries in the year concerned.

Abbreviations used for countries: EE- Estonia, LT - Lithuania, LV - Latvia, PL - Poland.

In the post accession period (2006-2017), the international competitive positions of the Baltic States' economies significantly changed. In 2006, Estonia was ranked the highest $\left(26^{\text {th }}\right.$ place and a score of 4.82$)$. Its position was much more favourable than those of Poland $\left(45^{\text {th }}\right.$ place and a score of 4.39 ), the Visegrad Group countries (on average, $38^{\text {th }}$ place and a score of 4.52) and the EU-10 ( $45^{\text {th }}$ place and a score of 4.43 respectively). The position of Lithuania was much worse $\left(39^{\text {th }}\right.$ place and a score of 4.47$)$ but still more favourable than those of Poland ${ }^{3}$ and of the EU-10 and similar to the position of the V4 countries. At that time, Latvia was ranked the lowest ( $44^{\text {th }}$ place and a score of 4.47$)$. The position of Latvia was similar to those of Poland and the EU-10 but much worse than the position of the V4 countries.

It is plain to see in Figure 1 and Figure 2 that in the period of the global economic crisis the competitive positions of the Baltic States deteriorated markedly. In 2009 (against 2006), Estonia moved down by 3 spots, Lithuania's position fell by 14 places, whereas that of Latvia dropped by as many as 24 spots. It is worth emphasising that - in the period in question Poland showed basically no change in rank (down by 1 place). At the same time, the positions of the V4 countries and of the EU-10 deteriorated by 8 and 7 spots respectively. Considering the above, it can be unambiguously stated that in merely 3 years the global economic crisis

\footnotetext{
${ }^{3}$ In the analysis presented, Poland - as earlier mentioned-was also used as a benchmark since it is one of the V4 countries, relatively the most successful in improving their international economic competitiveness in the postaccession period (for more see: Molendowski, 2017).
} 
dramatically affected the competitive positions of Lithuania and Latvia. The most 'resilient' economy proved to be that of Estonia.

That unfavourable trend was reversed by Estonia and Lithuania in 2010 and by Latvia as late as 2011. Subsequently, the countries covered steadily improved their competitive positions nearly every year. However, the improvement was not sufficient to restore, even in 8 years (until 2017), the 2006 position.

As a result of those developments, in 2017 all the Baltic States were ranked lower than in 2006. The most significant drop was observed in the case of Latvia (by as many as 10 spots

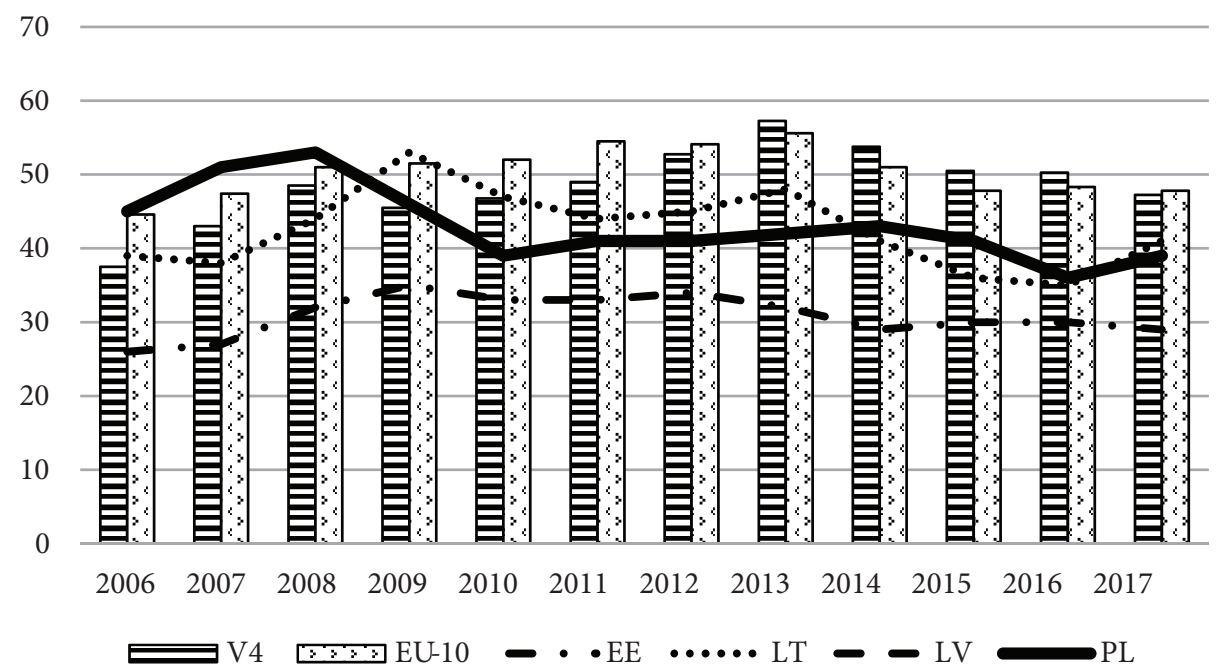

Figure 1. Competitive positions of the Baltic States against the backdrop of Poland, the V4 countries and the EU-10 in 2006-2017 (source: own study based on data as in Table 4)

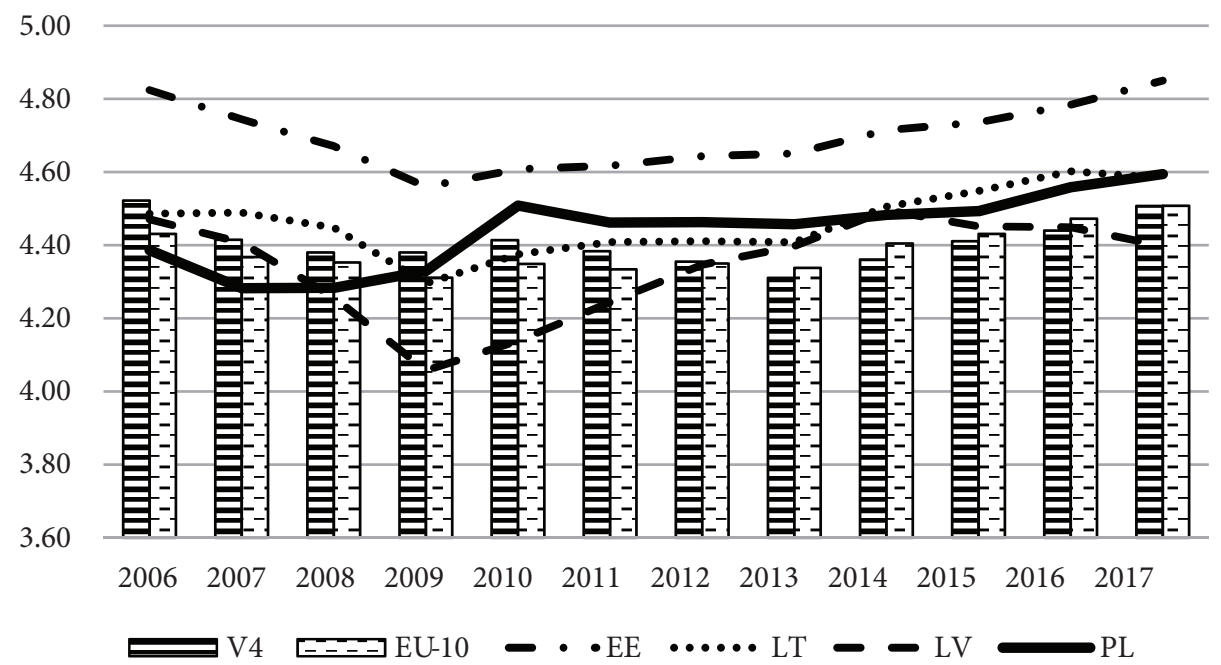

Figure 2. Competitive indices of the Baltic States against the backdrop of Poland, the V4 countries and the EU-10 in 2006-2017 (source: own study based on data as in Table 4) 
and by 0.07 in score). Although Estonia and Lithuania slightly improved their GCI scores (by 0.03 and 0.1 respectively), their competitive positions continued to be worse (by 3 and 2 places respectively). It is worth adding that in the same period the V4 countries and the EU-10 also deteriorated their competitive positions (moving down by 10 and 3 spots respectively). In contrast, in the period in question Poland improved its rank by 6 places and by 0.21 in score.

To recapitulate, it must be stated that throughout the period 2006-2017 the most favourable situation in terms of international competitive position was that of Estonia. However, Estonia was unable to match the achievement of the Polish economy (Centrum Analiz Społeczno-Ekonomicznych [CASE], 2019; Michałek \& Wilkin, 2019). A minor deterioration in the WEF ranking (down by 2 spots) was observed in Lithuania. Nevertheless, in 2017 Lithuania was ranked as low as $41^{\text {st }}$ place. In the case of the Estonian and Lithuanian economies, they followed the average trends for the EU-10. At the same time, an abrupt drop (by 10 spots) noted in the case of the Latvian economy was similar to the average situation in the V4 countries as a whole.

\section{Determinants of the competitive position of the Baltic States against the backdrop of the V4 countries and the EU-10}

As already mentioned above (cf. Table 3), it follows from The Global Competitiveness Reports prepared by the World Economic Forum that in the case of the countries under analysis (Lithuania, Latvia and Estonia) the 2006-2017 should have witnessed a much greater significance of efficiency enhancers as well as of innovation and sophistication factors in shaping their competitive positions. Whereas in 2006 basic requirements were to play a rather important role, by 2017 they should have diminished in importance (in favour of efficiency enhancers and of innovation and sophistication factors). In the analysis presented, it was decided to verify whether such a trend could be observed. The examination was based on the data shown in Table 5 and illustrated in Figure 3.

Table 5. Effects of specific factors on the competitive positions of the Baltic States (against the backdrop of Poland, the V4 countries and the EU-10) in 2006 and 2015 (source: Own calculations based on data as in Table 4)

\begin{tabular}{|c|c|c|c|c|c|c|c|c|c|c|c|c|}
\hline \multirow{2}{*}{ Pillars* } & \multicolumn{10}{|c|}{ GCI score in years } \\
\cline { 2 - 14 } & \multicolumn{9}{|c|}{2006} & \multicolumn{7}{c|}{2017} \\
\cline { 2 - 14 } & EE & LT & LV & PL & V-4 & EU-10 & EE & LT & LV & PL & V4 & EU-10 \\
\hline $\begin{array}{l}\text { GCI - } \\
\text { total }\end{array}$ & 4.82 & 4.49 & 4.47 & 4.39 & 4.52 & 4.43 & 4.85 & 4.58 & 4.40 & 4.59 & 4.51 & 4.51 \\
\hline $\begin{array}{l}\text { Basic } \\
\text { require- } \\
\text { ments }\end{array}$ & 5.28 & 4.91 & 4.84 & 4.62 & 4.76 & 4.77 & 5.66 & 5.15 & 5.01 & 4.99 & 4.95 & 5.01 \\
\hline 1. & 4.67 & 3.79 & 3.96 & 3.64 & 3.93 & 3.88 & 5.04 & 4.13 & 3.76 & 3.84 & 3.74 & 3.91 \\
\hline 2. & 4.34 & 4.04 & 3.85 & 3.29 & 3.00 & 3.75 & 5.09 & 4.65 & 4.40 & 4.70 & 3.31 & 4.48 \\
\hline 3. & 5.87 & 5.62 & 5.44 & 5.10 & 5.12 & 5.29 & 6.07 & 5.61 & 5.77 & 5.20 & 5.49 & 5.56 \\
\hline 4. & 6.25 & 6.19 & 6.09 & 6.46 & 4.55 & 6.16 & 6.43 & 6.20 & 6.11 & 6.22 & 4.54 & 6.09 \\
\hline
\end{tabular}


End of Table 5

\begin{tabular}{|c|c|c|c|c|c|c|c|c|c|c|c|c|}
\hline \multirow{3}{*}{ Pillars ${ }^{\star}$} & \multicolumn{12}{|c|}{ GCI score in years } \\
\hline & \multicolumn{6}{|c|}{2006} & \multicolumn{6}{|c|}{2017} \\
\hline & $\mathrm{EE}$ & LT & LV & $\mathrm{PL}$ & $\mathrm{V}-4^{\mathrm{a}}$ & $\mathrm{EU}-10^{\mathrm{a}}$ & $\mathrm{EE}$ & LT & $\mathrm{LV}$ & PL & $\mathrm{V} 4^{\mathrm{a}}$ & $\mathrm{EU}-10^{\mathrm{a}}$ \\
\hline $\begin{array}{l}\text { Effi- } \\
\text { ciency } \\
\text { enhan- } \\
\text { cers }\end{array}$ & 4.69 & 4.28 & 4.35 & 4.33 & 4.48 & 4.35 & 4.92 & 4.57 & 4.40 & 4.65 & 4.60 & 4.54 \\
\hline 5. & 5.22 & 4.93 & 4.89 & 4.73 & 4.75 & 4.73 & 5.52 & 5.16 & 4.95 & 4.98 & 4.77 & 4.91 \\
\hline 6. & 5.01 & 4.38 & 4.48 & 4.26 & 4.49 & 4.42 & 5.09 & 4.57 & 4.42 & 4.55 & 4.48 & 4.66 \\
\hline 7. & 4.74 & 4.43 & 4.58 & 4.44 & 4.49 & 4.45 & 5.02 & 4.33 & 4.47 & 4.14 & 4.21 & 4.30 \\
\hline 8. & 4.76 & 4.36 & 4.82 & 4.10 & 4.50 & 4.45 & 4.85 & 4.10 & 4.05 & 4.17 & 4.46 & 4.22 \\
\hline 9. & 5.05 & 3.79 & 3.87 & 3.39 & 3.97 & 3.90 & 5.91 & 5.62 & 5.27 & 4.89 & 5.14 & 5.27 \\
\hline 10. & 3.36 & 3.78 & 3.49 & 5.06 & 4.57 & 4.13 & 3.10 & 3.62 & 3.24 & 5.17 & 4.52 & 4.00 \\
\hline $\begin{array}{l}\text { Innova- } \\
\text { tion and } \\
\text { sophis- } \\
\text { tication } \\
\text { factors }\end{array}$ & 4.03 & 3.83 & 3.59 & 3.73 & 4.00 & 3.83 & 4.20 & 4.04 & 3.65 & 3.75 & 3.82 & 3.82 \\
\hline 11. & 4.38 & 4.31 & 4.11 & 4.03 & 4.36 & 4.22 & 4.36 & 4.35 & 4.07 & 4.11 & 4.15 & 4.10 \\
\hline 12. & 3.69 & 3.35 & 3.08 & 3.43 & 3.64 & 3.44 & 4.04 & 3.73 & 3.22 & 3.40 & 3.49 & 3.53 \\
\hline
\end{tabular}

Notes: Scores where the value for the pillar in question was higher than the overall GCI score are marked in grey.

* Pillar indications:

Basic requirements: $1^{\text {st }}$ pillar - Institutions, $2^{\text {nd }}$ pillar - Infrastructure, $3^{\text {rd }}$ pillar - Macroeconomic environment, $4^{\text {th }}$ pillar - Health and primary education;

Efficiency enhancers: $5^{\text {th }}$ pillar - Higher education and training, $6^{\text {th }}$ pillar - Goods market efficiency, $7^{\text {th }}$ pillar - Labour market efficiency, $8^{\text {th }}$ pillar - Financial market development, $9^{\text {th }}$ pillar - Technological readiness, $10^{\text {th }}$ pillar - Market size;

Innovation and sophistication factors: $11^{\text {th }}$ pillar - Business sophistication, $12^{\text {th }}$ pillar - Innovation.

2006

1.

12. 6.0

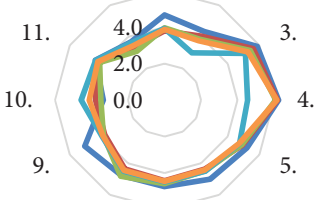

8.
6.

7.
2017

1.

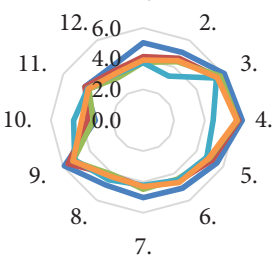

7.<smiles>C[P][In][Al][Al][Ba]</smiles><smiles>C[Pb][In][Al][Ba]</smiles>

Figure 3. Pilars of the competitive positions of the Baltic States (against the backdrop of the V4 countries and the EU-10) in 2006 and 2017

(source: Own study based on the data presented in Table 5) Note: Pillar indications - same as in Table 5. 
On the basis of the data presented in Table 4 and 5 (and in Figure 3), the following main trends in the development of the competitive positions of the Baltic States in 2006-2017 can be distinguished:

Estonia (EE): In 2006, the international competitive position of its economy was mostly shaped by basic requirements (with a score of 5.28, much higher than the overall GCI score of 4.82). Relatively the greatest role was played by the pillars of health and primary education (a score of 6.25) and of the macroeconomic environment (a score of 5.87). At the same time, efficiency enhancers mattered much less (with a score of 4.69 for the whole group, below the overall GCI score). However, in the group concerned the following stood out: health and primary education, technological readiness and goods market efficiency (with scores ranging from 5.22 to 5.01). Innovation and sophistication factors definitely proved to be the least important (with a score of 4.03).

In 2017, the most important role in shaping the competitive position of the Estonian economy was still played by basic requirements. The score for the whole group was 5.66 (against the overall GCI score of 4.85). In that group, as in 2006, the most important role was played by health and primary education (a score of 6.43) and the macroeconomic environment (a score of 6.07). It is also important to emphasise that the scores for all the pillars included in the group exceeded the overall GCI score. It means that they had strengthened their role in shaping the competitive position of the country concerned. As regards innovation and sophistication factors, there were no major changes (for the pillar of business sophistication, the score even showed a minor decrease).

A positive development among those observed in the case of Estonia in 2006-2017 was a distinct increase in the role of efficiency enhancers. The score for the whole group (4.92) was already markedly higher than the overall GCI score. It mostly resulted from combined improvements noted in the following pillars: technological readiness (a score of 5.91) and higher education and training (a score of 5.52). In addition, it is worth emphasising that in that group the scores for all the pillars were already higher than the overall GCI score. It means that the factors included in that group also strengthened their role in shaping the country's competitive position.

When comparing the developments observed in Estonia with trends noted in Poland, the V4 countries and the EU-10 in the period in question, it must be emphasised that a similarly improved role of efficiency enhancers was also seen in Poland and the V4 countries, although not to such a degree as in Estonia. But the EU-10 as a whole enjoyed no such improvement. Trends regarding basic requirements were similar in Estonia and in the other countries compared. At the same time, changes concerning innovation and sophistication factors (no significant changes in comparison with slightly diminished importance of the group in Poland, the V4 countries and the EU-10) can be described as positive.

Lithuania (LT): In 2006, the international competitive position of its economy was mostly shaped (as in Estonia) by basic requirements (with a score of 4.91, much above the overall GCI score of 4.49). Relatively the greatest role was played by the pillars of health and primary education (a score of 6.19) and of the macroeconomic environment (a score of 5.62). Efficiency enhancers had a much lesser influence (with a score of 4.28 for the whole group, markedly below the overall GCI score). One pillar stood out in the group: health 
and primary education (with a score of 4.93). The scores for other pillars included in the group were lower than the overall GCI score. Simultaneously, innovation and sophistication enhancers mattered the least (with a score of 3.83) to the development of the competitive position of Lithuania's economy.

In 2017, the most significant role in shaping the competitive position of the Lithuanian economy was still played by basic requirements. The score for the whole group was 5.15 (against the overall GCI score of 4.58). In that group, as in 2006, the most important role was played by health and primary education (a score of 6.20), the macroeconomic environment (a score of 5.61) and infrastructure (a score of 4.65). A significant improvement in comparison with 2006 was observed for the pillar of infrastructure (from a score of 4.34 to 4.65). It is also worth emphasising that the scores for 3 out of the 4 pillars included in the group exceeded the overall GCI score. It means that they had strengthened their role in shaping the competitive position of the country concerned. With regard to efficiency enhancers, no such marked improvement was noted. The score for the group (4.57) was similar to the overall GCI score. However, there was certain advancement in the pillars of technological readiness (with a score of 5.62) and higher education and training (5.16). Therefore, the factors included in that group basically showed no strengthened role in shaping the country's competitive position. As regards innovation and sophistication factors, no major changes were observed (scores for individual pillars were slightly above or similar to the 2006 levels).

In comparison with the most important trends with regard to determinants of the competitive positions of Poland, the V4 countries and the EU-10, in the case of Lithuania the situation was very similar (strengthened basic requirements and a minor improvement in efficiency enhancers). As far as innovation and sophistication factors are concerned, is it possible to say that maintaining in 2017 their importance at a level close to that noted for 2006 was a relatively positive development (against the stabilisation or even deterioration of the significance of that group in Poland, the V4 countries and the EU-10).

Latvia (LV): As demonstrated above (cf. Table 4), in 2006-2017 the Latvian economy suffered a significant deterioration of its international competitive position (down in the WEF ranking from $44^{\text {th }}$ to as low as $54^{\text {th }}$ place). Therefore, it seems interesting to explore which determinants contributed the most to the development.

In 2006, the international competitive position of the Latvian economy was mainly shaped (as in Estonia and Lithuania) by basic requirements (with a score of 4.84 , above the overall GCI score of 4.47). Relatively the greatest role was played by the pillars of health and primary education (a score of 6.09) and of the macroeconomic environment (a score of 5.44). At the same time, efficiency enhancers mattered much less (with a score of 4.35 for the whole group, below the overall GCI score). In the group - as in the case of Estonia and Lithuania the highest score (4.89) was obtained for the pillar of health and primary education. Other positively distinguished pillars included: financial market development (with a score of 4.82), labour market efficiency (4.58) and goods market efficiency (4.48). In 2006, definitely the least important role in shaping Latvia's competitive position was played by innovation and sophistication factors (with a score of 3.59).

In 2017, basic requirements still mattered the most to the development of the competitive position of the Latvian economy. The score for the whole group was 5.01 (against the overall 
GCI score of 4.40 and the 2006 score of 4.84), it was the most distinct increase in comparison with other sets of factors. In the group of basic requirements, as in 2006, the most important role was played by the pillars of health and primary education (with a score of 6.11) and the macroeconomic environment (a score of 5.77). It resulted in certain strengthening of the role of the whole group in shaping the overall competitive position of the country concerned. With regard to efficiency enhancers, no such marked improvement was noted. The score for the group (4.4) was identical with the overall GCI score. As regards innovation and sophistication factors, no considerable changes were observed (the score for the whole group was slightly above the 2006 level).

It is worth emphasising that in 2006-2017 Latvia was the only country among those studied where the overall GCI score went down (from 4.47 to 4.40 ). In the period in question, the most abrupt fall in score was noted in the group of basic requirements in the case of the pillar of institutions (by 0.20). There were also significant decreases in the set of efficiency enhancers, particularly in the case of the following pillars: financial market development (by 0.76), market size (by 0.25), labour market efficiency (by 0.11 ) and goods market efficiency (by 0.06). Scores dropped in as many as 6 out of the 12 pillars of competitiveness. It is worth emphasising that such steep decreases in scores for so many pillars were not noted in the case of Poland, the V4 countries or the EU-10. Therefore, it can be regarded as the main cause of the significant deterioration of the international competitive position of the Latvian economy in the period in question.

\section{Conclusions}

Based on the review of major publications presented in this article, the competitiveness of an economy should be described dynamically. It should take into account the development of available (domestic and foreign) production factors, the ability to grasp opportunities related to ongoing globalisation as well as the adaptability of businesses, sectors and the economy as a whole to changing conditions in the external environment. Such an approach to economic competitiveness was adopted by the authors of the Global Competitiveness Reports prepared by researchers associated with the World Economic Forum.

As a result of the accession to the European Union, the majority of the new Member States experienced rapid economic growth accompanied by restructuring and modernisation. It improved considerably the international competitive positions of their economies.

Obviously, in investigations of changes in the competitive positions of economies and their determinants a particular focus is on the study of long-term trends. Therefore, the analysis presented attempted to identify the most important trends characteristic of developments in the competitive positions of the countries covered in 2006-2017 or in 2017 against 2006.

In the post-accession period, Poland appeared to be one of the most successful in improving the international competitive position of its economy among the countries under examination (moving up in the WEF ranking by 6 spots, from $45^{\text {th }}$ place in 2006 to $39^{\text {th }}$ in 2017). In the group of the Baltic States, the most favourable situation in this regard was noted in the case of Lithuania and Estonia. Their ranks, however, dropped (by 23 spots respectively). Thus, the countries were unable to match the achievement of Poland. But in comparison 
with Latvia (as well as with the V4 countries and the EU-10), it was a distinct success. It is also worth emphasising that Estonia's $29^{\text {th }}$ place in the 2017 ranking was among the highest ranks for all the EU-10 (including the V4 countries and Poland). The rank of Lithuania was not significantly different from those of the V4 countries and the EU-10. The least favourable situation in this regard characterised Latvia (ranked $54^{\text {th }}$ in 2017), which meant relatively the worst position among all the countries under examination.

The most important trends observed in the development of the international competitive positions of the economies covered in the period under analysis were as follows:

- the strengthening of the role of basic requirements in shaping the competitive position. That trend was observed for all the countries covered. Among the pillars included in that group, the trend was the most distinct in the following: macroeconomic environment, health and primary education. In Estonia, Lithuania and Latvia (and in Poland) it was also observed in the pillar of infrastructure, whereas in the case of Estonia for the pillar of institutions as well. As recommended by the authors of The Global Competitiveness Reports, that group of factors should not gain in importance; - a slightly strengthened role of efficiency enhancers. That trend was the most evident in Estonia (in the case of all the pillars included in the group) and with regard to the pillars of higher education and training as well as technological readiness (in all the countries). In the case of Latvia, the 2017 scores for the pillars of goods market efficiency and labour market efficiency were higher than the overall GCI score but lower than in 2006. However, as recommended by the authors of The Global Competitiveness Reports, that group of factors should markedly gain in importance;

- no improvement with regard to the role of innovation and sophistication factors in the development of the competitive positions of the economies in question. That trend was observed for all the countries covered. As recommended by the authors of The Global Competitiveness Reports, that group of factors should at least play a slightly increasing role.

To sum up, those were the changes of a nature different from that suggested by the authors of The Global Competitiveness Reports.

An important element of the presented analysis was an attempt at verifying the assumption according to which the Baltic States should already (as recommended by the WEF) increasingly rely in building their international competitive positions mostly on efficiency enhancers and also to a growing degree on innovation and sophistication factors. It follows from the analysis conducted that in the period in question that trend was the most distinct only in the case of Estonia and, to a limited extent, for Lithuania. Characteristically, however, in the case of Poland efficiency enhancers gained in importance more markedly than in Estonia. Latvia built the competitive position of its economy mostly relying on basic requirements. The role of innovation and sophistication factors was rather limited in the Baltic States. In this regard, in 2017 the situation was nearly the same as in 2006. It is worth emphasising that similar patterns were noted in Poland as well as in the V4 countries and the EU-10. Therefore, the actually observed trends were different from those recommended by the WEF experts. It seems that in the years to come the Baltic States (especially Latvia but also Lithuania) should - to a greater degree than before - build their competitive positions based on efficiency enhancers, particularly those not appreciated enough in the past. 
Latvia should pay the most attention to the following pillars: financial market development, labour market efficiency, goods market efficiency. As regards Lithuania, improvement should be achieved in the pillars of financial market development and labour market efficiency. Financial market development and goods market efficiency represent pillars which should gain importance in the case of Estonia. In the group of innovation and sophistication factors, in all the countries covered the pillar of business sophistication needs much improvement. The Baltic States should draw on certain experiences of Poland and of the Czech Republic in this area.

At this stage, the limited scope of the study presented in the article did not allow to formulate answers to the emerging questions. Those problems should be addressed by further research on the subject. It seems the most advisable to attempt to find answers to the following questions:

- why do the Baltic States still fail to build their international competitive positions based on efficiency enhancers as well as on innovation and sophistication factors?

- which of the experiences of Poland and of other Visegrad Group countries in the development of the international competitive position should be used by the Baltic States?

- what are the most important changes that should be introduced to the economic policies of the Baltic States in order to improve their international competitive positions?

It seems that the analysis presented in this article may be a significant basis for the continuation of such studies and for attempts to answer those questions.

\section{Acknowledgements}

The Author (Edward Molendowski) acknowledges and is grateful for the financial support provided by the National Science Centre (Poland) under Grant No. 2015/17/B/HS4/02075.

\section{Disclosure statement}

The authors has no competing financial, professional or personal interests from other parties.

\section{References}

Bossak, J. (2000). Międzynarodowa konkurencyjność gospodarki kraju i przedsiębiorstwa. Zagadnienia teoretyczne i metodologiczne. In W. Bieńkowski (Ed.), Konkurencyjność gospodarki Polski w dobie integracji $z$ Uniq Europejską. SGH.

Centrum Analiz Społeczno-Ekonomicznych. (2019). Nasza Europa: 15 lat Polski w Unii Europejskiej. Warszawa. http://www.case-research.eu/files/?id_plik=5987

Cohen, S. S. (1994). Speaking freely. Foreign Affairs, 73(4), 194-197. https://doi.org/10.2307/20046818

Espona, R. J. (2018). Lithuania, Latvia and Estonia: The Euro-Atlantic consolidation of the Baltic region. Institute for International Relations and Political Science. TSPMI-University of Vilnius. http://www. realinstitutoelcano.org/wps/portal/rielcano_en/contenido?WCM_GLOBAL_CONTEXT=/elcano/ elcano_in/zonas_in/ARI-97-2018-Espona-Lithuania-Latvia-Estonia-Euro-Atlantic-consolidationBaltic-region 
Falkowski, K. (2018). Competitiveness of the Baltic States in International High-Technology Goods Trade. Comparative Economic Research, 21(1), 25-43. https://doi.org/10.2478/cer-2018-0002

Gomułka, M., \& Czajkowski, Z. (2008). Konkurencyjność międzynarodowa - pojęcie i metodologia pomiaru; Materiały do dyskusji. In W. Bieńkowski \& M. A. Weresa (Eds.), Czynniki i miary międzynarodowej konkurencyjności gospodarek w kontekście globalizacji - wstępne wyniki badań. SGH.

Howes, C. (2000). U.S. Competitiveness and economic growth. In C. Howes \& A. Singh (Eds.), Competitiveness matters: Industry and economic performance in the U.S. The University of Michigan Press. https://doi.org/10.3998/mpub.16353

International Institute for Management Development. (2017). IMD World competitiveness yearbook 2017. Lausanne.

Jagiełło, E. M. (2008). Strategiczne budowanie konkurencyjności gospodarki. Poltext.

Kerikmäe, T., Chochia, A., \& Atallah, M. (2018). The Baltic States in the European Union. In Oxford Research Encyclopaedia. Politics. https://doi.org/10.1093/acrefore/9780190228637.013.186

Krugman, P. (1994). Competiveness: A dangerous obsession. Foreign Affairs, 73(2), 28-44. https://doi.org/10.2307/20045917

Martin, R. (2003). A study on the factors of regional Competitiveness. Final report for The European Commission Directorate-General Regional Policy. University of Cambridge.

Michałek, J. J., \& Wilkin, J. (2019). Unia Europejska - źródło cennych korzyści ekonomicznych dla Polski. In R. Kuźniar (Ed.), Jestem obywatelem Unii Europejskiej. Wydawnictwo Naukowe Scholar.

Misala, J. (2009). Historia rozwoju teorii i polityki konkurencyjności międzynarodowej. SGH.

Misala, J. (2011). Międzynarodowa konkurencyjność gospodarki narodowej. PWE.

Misztal, P. (2009). International competitiveness of the Baltic States in the transformation period: Lithuania, Latvia and Estonia. Transformations in Business \& Economics, 8(3), 21-35.

http://www.transformations.knf.vu.lt/18/ge18.pdf

Molendowski, E., \& Folfas, P. (2019). Effects of the pillars of competitiveness on the competitive positions of Poland and of the Visegrad Group Countries in the post-accession period. Comparative Economic Research, 22(2), 55-67. https://doi.org/10.2478/cer-2019-0012

Molendowski, E. (2015). 10 years of membership in the European Union - Poland in Comparison with the Visegrad Group Countries. Central European Review of Economics \& Finance, 10(4), 5-18.

Molendowski, E. (2017). An internationally competitive economy: A comparison of Poland and the Visegrad Group countries in the post-accession period. Comparative Economic Research, 20(4), 5-21. https://doi.org/10.1515/cer-2017-0025

Prestowitz, C.V. Jr. (1994). Playing to win. Foreign Affairs, 73(4), 186-188. https://doi.org/10.2307/20046815

Radło, M. J. (2008). Międzynarodowa konkurencyjność gospodarki. Uwagi na temat definicji, czynników i miar. In W. Bieńkowski \& M. A. Weresa (Eds.), Czynniki i miary międzynarodowej konkurencyjności gospodarek $w$ kontekście globalizacji - wstępne wyniki badań. SGH.

Reinert, E. (1995). Competitiveness and its predecessors - a 500 year across national perspective. Structural Change and Economic Dynamics, 6(1), 23-42. https://doi.org/10.1016/0954-349X(94)00002-Q

The World Bank. (2018). Doing Business 2018 - Reforming to Create Jobs. Washington DC. http://www.doingbusiness.org/content/dam/doingBusiness/media/Annual-Reports/English/ DB2018-Full-Report.pdf

Thurow, L. C. (1994). Microchips, not potato chips. Foreign Affairs, 73(4), 189-192. https://doi.org/10.2307/20046816

United Nations Development Programme. (2018). Human development indices and indicators 2018 statistical update. New York.

http://hdr.undp.org/sites/default/files/2018_human_development_statistical_update.pdf 
Weresa, M. A. (2008). Definicje, determinanty oraz sposoby pomiaru konkurencyjności krajów. In W. Bieńkowski \& M. A. Weresa (Eds.), Czynniki i miary międzynarodowej konkurencyjności gospodarek $w$ kontekście globalizacji - wstępne wyniki badań. SGH.

Weresa, M. A. (2018). Innovation Union initiative - an overview. In M. A. Weresa (Ed.), Strengthening the knowledge base for innovation in the European Union. SGH.

Wołkonowski, J. (2018). Kraje Bałtyckie w strefie euro. In W. M. Orłowski, Jak żyć z euro? Doświadczenia krajów Europy Środkowo-Wschodniej. Polska Fundacja im. Roberta Schumana.

http://schuman.pl/wp-content/uploads/2019/01/Jak-\%C5\%BCy\%C4\%87-z-euro_raport-FundacjiSchumana.pdf

Wołkonowski, J. (2019). The Beta-convergence of the EU-10 countries and regions in the years 20042015. Comparative Economic Research, 22(2), 87-104. https://doi.org/10.2478/cer-2019-0014

World Economic Forum. (2006). Global Competitiveness Report 2006-2007. Geneva.

World Economic Forum. (2008). Global Competitiveness Report 2008-2009. Geneva.

World Economic Forum. (2015). The Global Competitiveness Index Historical Dataset (c) 2005-2015. Geneva.

World Economic Forum. (2017). The Global Competitiveness Report 2017-2018. K. Schwab (Ed.). Geneva.

Wysokińska, Z. (2001). Konkurencyjność w międzynarodowym i globalnym handlu technologiami. PWN.

Wziątek-Kubiak, A. (2001). Międzynarodowa specjalizacja a konkurencyjność. Ekonomista, 4, 471-491.

Wziątek-Kubiak, A. (2004). Kontrowersje wokół konkurencyjności w teorii ekonomii. Ekonomista, 6, 805-807.

Żmuda, M., \& Molendowski, E. (2016). W poszukiwaniu istoty konkurencyjności gospodarki narodowej: studium interdyscyplinarne. Finanse, Rynki Finansowe, Ubezpieczenia, 3(81), 323-333. https://doi.org/10.18276/frfu.2016.81-28 